\title{
Impact of ventilation heat recovery on primary energy use of apartment buildings built to conventional and passive house standard
}

\author{
Leif Gustavsson $^{1,2}$, Ambrose Dodoo $^{2, *}$, Roger Sathre ${ }^{2}$ \\ ${ }^{1}$ Linnaeus University, 35195 Växjö, Sweden \\ ${ }^{2}$ Mid Sweden University, 83125 Östersund, Sweden \\ * Corresponding author. Tel: +46 63165383 , Fax: +46 63165500, E-mail: ambrose.dodoo@miun.se
}

\begin{abstract}
In this study we analyze the primary energy implications of ventilation heat recovery (VHR) in residential buildings, considering the entire energy chains. We calculate the operation primary energy use of a case-study apartment building built to conventional and passive house standard, both with and without VHR, and heated with electric resistance heating, bedrock heat pump or district heating. VHR increases the electrical energy used for ventilation and reduces the heat energy used for space heating. The primary energy savings of VHR are greater for the passive building than for the conventional building. Significantly more primary energy is saved when VHR is used in resistance heated buildings than in district heated buildings. For district heated buildings the primary energy savings are small. VHR systems can give substantial final energy reduction, but the primary energy benefit depends strongly on the type of heat supply system, and also on the amount of electricity used for VHR and the airtightness of buildings. This study shows the importance of considering the interactions between heat supply systems, VHR systems, building thermal properties and its airtightness to reduce primary energy use in buildings.
\end{abstract}

Keywords: Mechanical ventilation; Heat recovery; Heat supply systems; Electric resistance heating; Heat pumps; District heating; CHP plant; Primary energy.

\section{Introduction}

Ventilation has a significant impact on the energy performance of buildings, accounting for 30 to $60 \%$ of the energy use in buildings $[1,2]$. Energy is used to cover the heat losses due to the ventilation air and to move the ventilation air for mechanical ventilation. The ventilation system also influences the air infiltration through the building envelope.

Building regulations currently require high energy efficiency of buildings, and therefore considerable efforts have been made to improve airtightness and insulation of buildings. In such buildings mechanical ventilation with heat recovery (VHR) is often used to recover heat from exhaust air to reduce ventilation heat losses. Ventilation heat losses can be typically 35 $40 \mathrm{kWh} / \mathrm{m}^{2}$-year in residential buildings, and up to $90 \%$ of this can be recovered with VHR depending on airtightness and insulation of buildings [3]. VHR is therefore gaining increasing interest in low energy and retrofitted buildings. In very low energy buildings, such as passive house buildings, VHR units are often equipped with additional air heaters to cover the space heating demand.

Sweden has set targets to reduce the final energy use per heated building area by $20 \%$ and $50 \%$ by 2020 and 2050, respectively, using 1995 as the reference [4]. Heat recovery from exhaust ventilation air is considered an important means to reach this target, and increased attention is being placed on VHR. There is a technology procurement project to develop and promote VHR systems which can be adapted for existing Swedish apartment buildings [5].

Most studies on the energy impact of VHR have focused on final energy use [e.g. 6-8]. Primary energy use, in contrast to final energy use, largely determines the natural resource use and the environmental impact of end-use energy services. The concept of primary energy is used to denote the total energy needed in order to generate the final energy service, including 
inputs and losses along the entire supply chains. Fewer studies have analyzed the primary energy implication of VHR in buildings. In this study, we analyze the impact of VHR on the operation primary energy use for residential buildings. We determine situations where mechanical ventilation with heat recovery can reduce primary energy use for building operation.

\section{Methodology}

This analysis is based on simulation modeling of a case-study apartment building with mechanical ventilation. We model the primary energy use for the original and improved level of energy efficiency of the building, both with and without VHR. Next we compare the primary energy use of the buildings and calculate the net primary energy savings achieved by the VHR, taking into account the changed electricity use due to VHR, as well as the changed heat demand due to VHR and changed air infiltration.

\subsection{Building description}

Our case-study building is a 4-storey multi-family wood-frame building with 16 apartments and a total heated floor area of $1190 \mathrm{~m}^{2}$. Persson [9] describes the construction and thermal characteristics of the building in detail. A new building is then modeled with thermal properties of passive house but otherwise identical to the existing building. Table 1 shows the thermal characteristics of the existing, conventional building and the new, passive building. In addition to lower U-values, the passive building is assumed to have much better airtightness than the conventional building.

Table 1. Thermal properties of the building components

\begin{tabular}{lcccccc}
\hline Building & \multicolumn{9}{c}{$U$-value $\left(W / \mathrm{m}^{2} \mathrm{~K}\right)$} & Air leakage \\
\cline { 2 - 6 } & $\begin{array}{c}\text { Ground } \\
\text { floor }\end{array}$ & $\begin{array}{c}\text { External } \\
\text { walls }\end{array}$ & Windows & Doors & Roof & $\begin{array}{c}1 / \mathrm{s} \mathrm{m}^{2} \\
\text { at } 50 \mathrm{~Pa}\end{array}$ \\
\hline Conventional & 0.23 & 0.20 & 1.90 & 1.19 & 0.13 & 0.8 \\
Passive & 0.23 & 0.10 & 0.85 & 0.80 & 0.08 & 0.3 \\
\hline
\end{tabular}

For both the conventional and passive buildings, we analyze the use of mechanical ventilation with and without VHR. The designed airflow rate for the building is $0.351 / \mathrm{s} \mathrm{m}^{2}$, based on Swedish regulations [10]. For the buildings without VHR, exhaust air is extracted from the kitchens, bathrooms and closets with fan and duct system, and fresh air is supplied through slot openings under windows in the bedrooms and living rooms. For the buildings with VHR, the ventilation system provides the same airflow rate as in the buildings without VHR. For the existing, conventional building the existing ventilation system is complemented with ventilation ducts for incoming air and a heat recovery unit [5].

\subsection{Heat supply}

We analyze cases where space heat is delivered by electric resistance heating, heat pump or district heating. For the electric resistance heating and heat pump we assume that the electricity is supplied from a stand-alone plant based on biomass steam turbine (BST) technology. We assume that the district heat is supplied from a combined heat and power (CHP) plant based on biomass steam turbines technology (CHP-BST). We consider scenarios where the CHP plant accounts for either $50 \%$ or $90 \%$ of the district heat production, with oil boilers accounting for the remainder. To show the impact of energy supply technology being developed, we also analyze a cas e where biomass integrated gasification combined cycle (BIGCC) technology is used instead of the BST technology for both CHP and stand-alone 
power production. Furthermore, Gustavsson et al. [11] explored the structure of district heat production under different environmental taxation regimes. They found that the CHP production should be $80-83 \%$ of the total district-heat production when using BST technology and $76-78 \%$ when using BIGCC technology. The difference in share of district-heat production between the technologies varies because the BIGCC technology is more efficient and capital intensive than the BST technology. To explore the implications of this for VHR, we calculate the primary energy savings when district heating is based on s uch CHP production systems.

\subsection{Final energy calculations}

We simulate the annual final energy use of the conventional and the passive buildings, both with and without VHR, using the ENORM software [12]. This software calculates the space heating, ventilation, domestic hot water, and household and facility management electricity use of a building based on the building's physical characteristics, internal and solar heat gains, occupancy pattern, outdoor climate, indoor temperature, heating and ventilation systems, etc. We use climate data for the city of Växjö in southern Sweden, and assume an indoor temperature of $22^{\circ} \mathrm{C}$. Table 2 shows principal values used to calculate the electricity use for ventilation. Other values including fan efficiency and operation mode of the ventilation systems are based on the default assumptions of the ENORM software.

Table 2. Major ventilation input values

\begin{tabular}{lr}
\hline Description & Value \\
\hline Air change rate $\left(1 / \mathrm{s} \mathrm{m}^{2}\right)$ & 0.35 \\
Heat recovery efficiency $(\%)$ & 85 \\
Ventilated volume $\left(\mathrm{m}^{3}\right)$ & 2861 \\
Supply air flow rate $\left(\mathrm{m}^{3} / \mathrm{h}\right)$ & 1540 \\
\hline
\end{tabular}

\subsection{Primary energy calculations}

We use the ENSYST software [13] to quantify the primary energy that is used to provide the final energy use in the different cases. The software calculates primary energy use considering the entire energy chain from natural resource extraction to final energy supply. We credit the electricity cogenerated by the CHP plant to the district heat system, assuming that it replaces electricity produced by a stand-alone plant with similar technology and fuel [14]. We assume the increased electricity use due to VHR is covered by stand-alone plant with similar technology and fuel as the heat supply system used.

\section{Results}

Table 3 compares the annual final energy use of the conventional and the passive buildings with and without VHR. The annual total final energy use of the passive building with VHR is about $21 \%$ lower than for the alternative without VHR. The corresponding value for the conventional building with VHR is $10 \%$. VHR decreases the final energy for space heating, but increases the electricity used to operate the ventilation system. Overall, VHR reduces the final energy for space heating and ventilation by 55 a nd $22 \%$ for the passive and the conventional building, respectively, relative to the alternatives without VHR. 
Table 3. Annual final operation energy use for the building scenarios

\begin{tabular}{lccccc}
\hline Building & \multicolumn{5}{c}{ Final energy use $\left(\mathrm{kWh} / \mathrm{m}^{2}\right.$-year $)$} \\
\cline { 2 - 6 } & $\begin{array}{c}\text { Space } \\
\text { heating }\end{array}$ & $\begin{array}{c}\text { Ventilation } \\
\text { electricity }\end{array}$ & $\begin{array}{c}\text { Tap } \\
\text { water } \\
\text { heating }\end{array}$ & $\begin{array}{c}\text { Household } \\
\text { and facility } \\
\text { electricity }\end{array}$ & Total \\
\hline Conventional building & 70 & 4 & 40 & 52 & 166 \\
Conventional building with VHR & 50 & 8 & 40 & 52 & 150 \\
Passive building & 43 & 4 & 40 & 52 & 143 \\
Passive building with VHR & 13 & 8 & 40 & 52 & 113 \\
\hline
\end{tabular}

Table 4 shows the annual operation primary energy use for the conventional and the passive buildings when using different end-use heating systems with energy supply based on B ST technology. Ventilation accounts for $2-11 \%$ of the operation primary energy use. The primary energy for heating for the district heated buildings is low due to the high overall efficiency of district heating systems with CHP plants. The cogenerated electricity replaces electricity that otherwise would have been produced in a stand-alone plant with much lower efficiency.

Table 4. Annual operation primary energy use for the building with different end-use heating systems with energy supply based on BST technology

\begin{tabular}{lccccc}
\hline Description & \multicolumn{5}{c}{ Primary energy use $\left(\mathrm{kWh} / \mathrm{m}^{2}\right.$-year $)$} \\
\cline { 2 - 6 } & $\begin{array}{c}\text { Space } \\
\text { heating }\end{array}$ & $\begin{array}{c}\text { Ventilation } \\
\text { electricity }\end{array}$ & $\begin{array}{c}\text { Tap } \\
\text { water } \\
\text { heating }\end{array}$ & $\begin{array}{c}\text { Household } \\
\text { and facility } \\
\text { electricity }\end{array}$ & Total \\
\hline Resistance heating: & & & & & \\
Conventional building & 209 & 12 & 119 & 155 & 496 \\
Conventional building with VHR & 149 & 24 & 119 & 155 & 448 \\
Passive building & 128 & 12 & 119 & 155 & 415 \\
Passive building with VHR & 39 & 24 & 119 & 155 & 337 \\
\hline Heat pump: & & & & & \\
Conventional building & 78 & 12 & 45 & 155 & 290 \\
Conventional building with VHR & 55 & 24 & 45 & 155 & 280 \\
Passive building & 48 & 12 & 45 & 155 & 260 \\
Passive building with VHR & 14 & 24 & 45 & 155 & 239 \\
\hline District heating, 50\% CHP: & & & & & \\
Conventional building & 66 & 12 & 38 & 155 & 271 \\
Conventional building with VHR & 47 & 24 & 38 & 155 & 264 \\
Passive building & 41 & 12 & 38 & 155 & 246 \\
Passive building with VHR & 12 & 24 & 38 & 155 & 229 \\
\hline District heating, 90\% CHP: & & & & & \\
Conventional building & 42 & 12 & 24 & 155 & 233 \\
Conventional building with VHR & 30 & 24 & 24 & 155 & 233 \\
Passive building & 26 & 12 & 24 & 155 & 217 \\
Passive building with VHR & 8 & 24 & 24 & 155 & 211 \\
\hline & & & & & \\
\hline
\end{tabular}

Table 5 compares the percentage primary energy savings of VHR in relation to the primary energy use for space heating and ventilation, and to the total p rimary energy use for operation, including space heating, ventilation electricity, tap water heating and household and facility management electricity. The VHR primary energy savings ranges from $0-55 \%$ of space heating and ventilation primary energy use. 
Table 5. Percentage primary energy savings of VHR, in relation to the primary energy used for space heating and ventilation for the different end-use heating systems with BST energy supply technology

\begin{tabular}{lcccc}
\hline Building & \multicolumn{4}{c}{ Relative primary energy savings } \\
\cline { 2 - 5 } & $\begin{array}{c}\text { Resistance } \\
\text { heating }\end{array}$ & $\begin{array}{c}\text { Heat } \\
\text { pump }\end{array}$ & $\begin{array}{c}\text { District heating, } \\
50 \% \text { CHP }\end{array}$ & $\begin{array}{c}\text { District heating, } \\
90 \% \text { CHP }\end{array}$ \\
\hline Conventional & $22 \%$ & $12 \%$ & $9 \%$ & 0 \\
Passive & $55 \%$ & $37 \%$ & $32 \%$ & $16 \%$ \\
\hline
\end{tabular}

The change in annual primary energy use for space heating and ventilation electricity when using VHR with different end-use heating system with BST or BIGCC energy supply are shown in Figure 1. T he net savings are shown in Figure $2 \mathrm{f}$ or both BST and BIGCC technologies. The primary energy savings of VHR is significantly greater when using resistance heating, followed by heat pump and district heating with $50 \%$ CHP. However, much smaller or no primary energy savings is achieved when using district heating with $90 \%$ CHP. The savings of VHR are larger for the passive building than for the conventional building. The BIGCC technology gives similar results as the BST technology, but the net primary energy savings are lower compared to the case of BST.

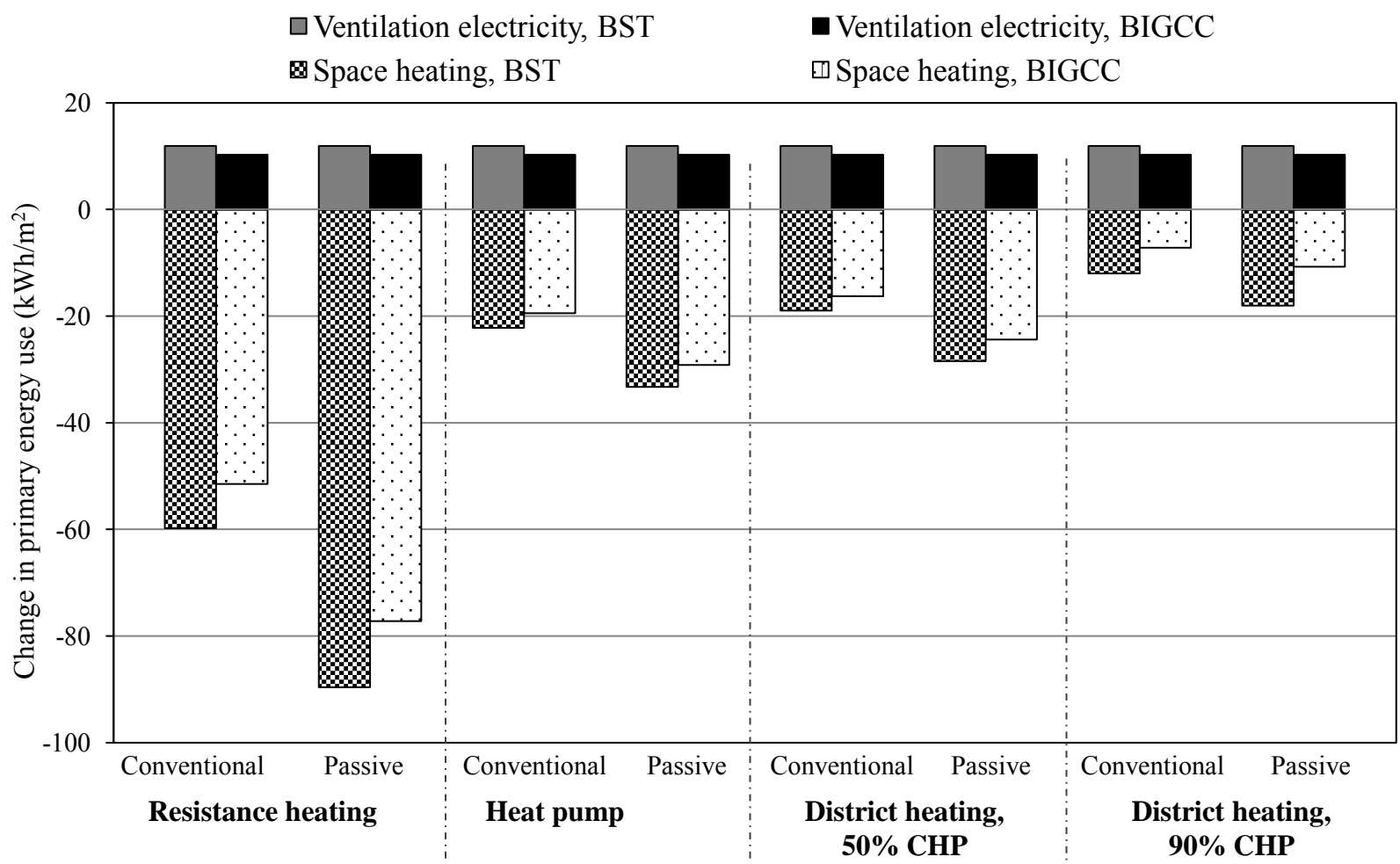

Figure 1. Change in annual primary energy use for space heating and ventilation electricity when using VHR with BST or BIG/CC energy supply 


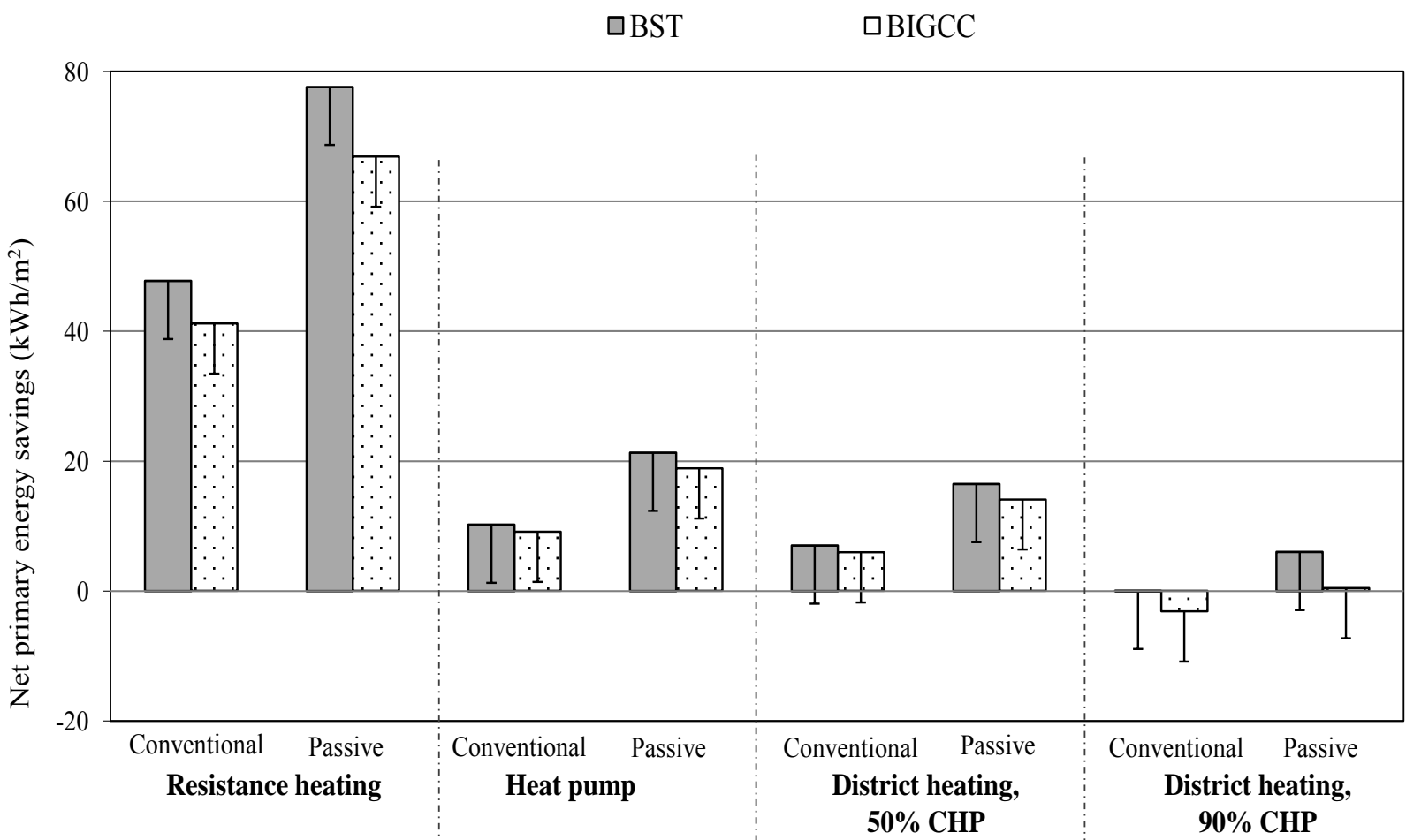

Figure 2. Net annual primary energy savings for VHR when using BST or BIGCC energy supply. The error bars show the savings when electricity use by the VHR is $7 \mathrm{kWh} / \mathrm{m}^{2}$

In cold climatic regions VHR systems usually encounter frost during severe winters, and additional energy may be needed for defrosting. VHR systems may be fitted with additional preheating device to overcome this problem, increasing the electricity use for VHR [15]. Our base calculations are based on electricity use of $4 \mathrm{kWh} / \mathrm{m}^{2}$ for the VHR and do not include electricity to defrost the system. Tommerup and Svendsen [3] reported that electricity use in VHR system of $80-90 \%$ efficiency is typically $7 \mathrm{kWh} / \mathrm{m}^{2}$ under Danish conditions, and suggested this might be reduced to $3 \mathrm{kWh} / \mathrm{m}^{2}$ with more efficient systems. In Figure 2 the error bars show the change in net primary energy savings for VHR, when the electricity use for VHR is $7 \mathrm{kWh} / \mathrm{m}^{2}$ instead of $4 \mathrm{kWh} / \mathrm{m}^{2}$. The higher electricity use for operating VHR reduces the net primary energy savings, in particular for the district heated buildings. In fact, a ventilation electricity use of $7 \mathrm{kWh} / \mathrm{m}^{2}$ increases the net primary energy use for the buildings with district heating based on 90\% CHP. Hence low electricity use for VHR is important. For the conventional building with lower airtightness together with district heating based on a large share of CHP production, VHR may be counterproductive and increase primary energy use.

In our base case calculations, the CHP production accounts for 50 and $90 \%$ of the total district heat production [16]. In this section, we show the net primary energy savings for VHR when more optimally designed CHP production systems are used. Figure 3 shows the net primary energy savings for VHR when district heating is based on the lower and upper optimal CHP productions according to Gustavsson et al. [11]. VHR increases net primary energy use for all buildings when the electricity use for VHR is $7 \mathrm{kWh} / \mathrm{m}^{2}$. The net savings is positive, but very low, for the conventional buildings with VHR systems using $4 \mathrm{kWh} / \mathrm{m}^{2}$. 


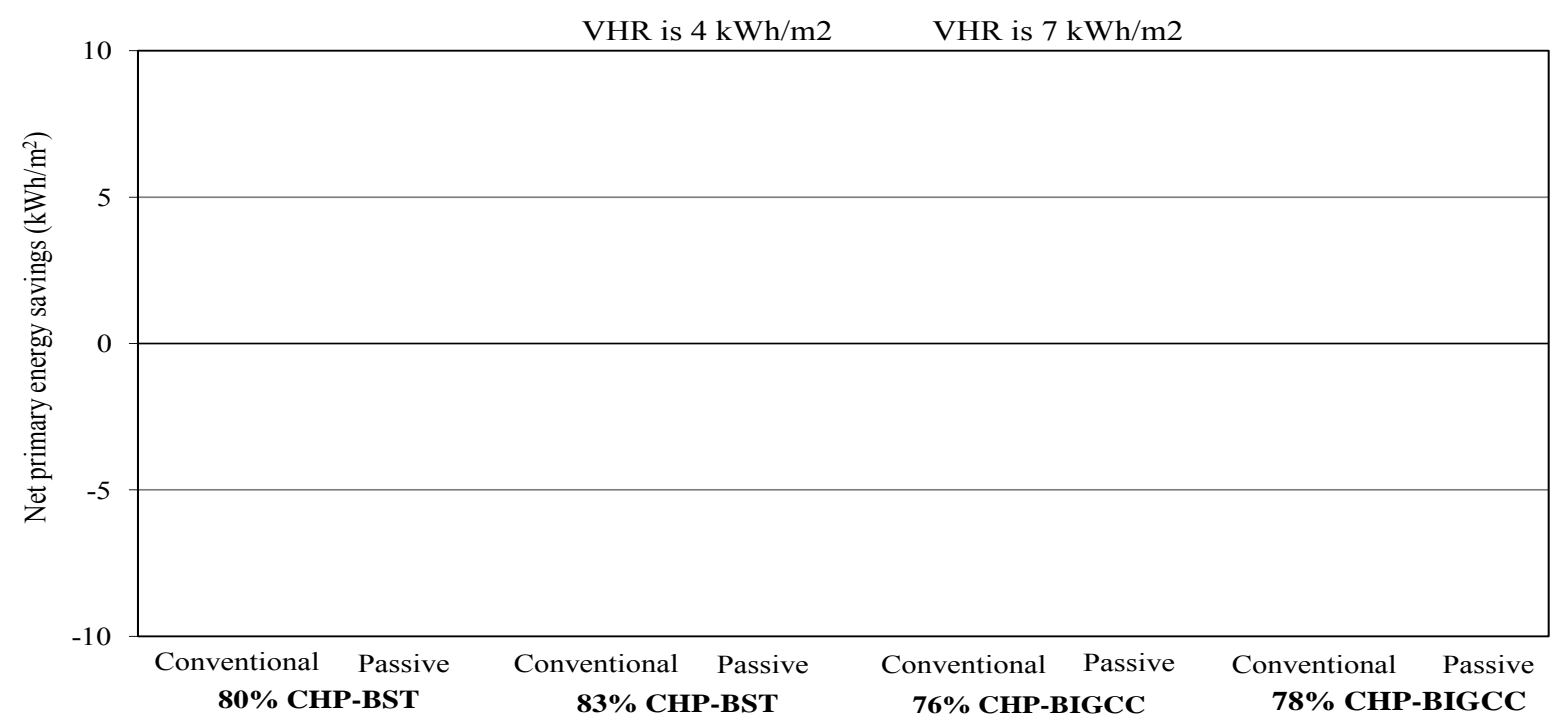

Figure 3. Net annual primary energy savings for VHR when more optimally designed CHP production systems are used

\section{Discussion and conclusions}

Our results show that primary energy savings of VHR can be very significant, depending on the type of heat supply system, the airtightness and thermal properties of buildings, and the amount of increased electricity used to operate the VHR system. The biggest savings is achieved when VHR is installed in a resistance heated building. However, small primary energy savings is achieved when the VHR is installed in CHP-based district heated buildings. VHR gives much smaller primary energy savings for the district heating with $90 \%$ CHP than with 50\% CHP, supporting the findings of Dodoo et al. [16] and Gustavsson et al. [11]. For district heating systems mainly based on CHP, the reduced heat demand reduces the potential to cogenerate electricity, and is more significant if BIGCC technology is used instead BST technology.

The primary energy savings of VHR are greater for the passive building than for the conventional building, confirming that VHR systems perform better with improved airtightness $[3,6]$. Hence, the air-tightness of buildings should be in the range as for newly constructed passive houses to minimize primary energy use when using VHR systems. We found that the greatest primary energy savings is achieved when VHR is incorporated in resistance heated passive building. The primary energy savings of VHR depend on the electricity use to operate the VHR system. Therefore the amount of electricity required to operate VHR system should be minimized.

Our results show that VHR may give low or negative primary energy savings in passive house buildings when combined with energy-efficient heat supply systems. For example, the casestudy passive building with VHR in some cases uses greater primary energy than the same building without VHR. It is important to build houses with airtightness comparable to that of passive houses but such houses need to be ventilated using strategies that minimize primary energy use.

When deciding on i nstalling VHR, attention should therefore be given to the interaction between the electricity use for VHR, the airtightness of the building and the type of heat supply system. This is particularly important when using district heating with a large share of 
CHP production, as suggested by Dodoo et al. [16]. A primary energy analysis is necessary to evaluate the energy benefits of VHR in residential buildings.

\section{References}

[1] H.B. Awbi, Chapter 7-Ventilation, Renewable and Sustainable Energy Reviews, 2(1-2), 1998, pp. 157-188.

[2] M. Orme, Estimates of the energy impact of ventilation and associated financial expenditures, Energy and Buildings, 33 (3), 2001, pp. 199-205.

[3] H. Tommerup, and S. Svendsen, Energy savings in Danish residential building stock, Energy and Buildings, 38 (6), 2006, pp. 618-626.

[4] Swedish Government Bill 2005/06:145. A national programme for energy efficiency and energy smart construction. Web accessed at http://www.regeringen.se on April 20, 2009.

[5] Å. Wahlström, A. Blomsterberg, and D. Olsson, Värmeåtervinningssystem för befintliga flerbostadshus, Förstudie inför teknikupphandling, 2009.

[6] D. Hekmat, H. E. Feustel, and M. P. Modera. Impacts of ventilation strategies on energy consumption and indoor air quality in single-family residences, Energy and Buildings, 9 (3), 1986, pp. 239-251.

[7] R. Lowe, and D. Johnston, Mechanical ventilation with heat recovery in Local Authority, low-rise housing: Final report on the Derwentside Field Trial. Leeds: Leeds Metropolitan University, 1997.

[8] TIP-Vent, Towards improved performances of mechanical ventilation systems, 2001. http://www.inive.org/Documents/Tip-Vent_Source_Book.pdf on March 1, 2010.

[9] S. Persson, Wälludden trähus i fem våningar: Erfarenheter och lärdomar, Report TVBK3032, Department of Structural Engineering, Lund Institute of Technology, Sweden, 1998.

[10]Boverkets, Byggregler: Boverkets Författningssamling. Karlskrona: The National Board of Housing, Building and planning, 2009.

[11]L. Gustavsson, A. Dodoo, N.L. Truong, and I. Danielski, Primary energy implications of end-use energy efficiency measures in district heated buildings, Energy and Buildings, 43 (1), 2011, pp. 38-48.

[12]EQUA (Simulation AB), ENORM, Version 1000, Stockholm, Sweden, 2004.

[13] Å. Karlsson, ENSYST, Version 1.2, Lund University, Sweden, 2003.

[14]L. Gustavsson, and $\AA$. Karlsson, CO2 mitigation: on methods and parameters for comparison of fossil-fuel and biofuel systems, Mitigation and Adaptation Strategies for Global Change, 11(5-6), 2006, pp. 935-959.

[15]J. Kragh, J. Rose, T.R. Nielsen, and S .Svendsen, New counter flow heat exchanger designed for ventilation systems in cold climates, Energy and Buildings, 39 (11), 2007, pp. 1151-1158.

[16]A. Dodoo, L. Gustavsson, and R. Sathre, Life cycle primary energy implication of retrofitting a Swedish apartment building to passive house standard, Resources, Conservation and Recycling, 54 (12), 2010, pp. 1152-1160. 